\title{
Analisis Keuntungan dan Efisiensi Usaha Susu Pasteurisasi di Koica Milk Shop Kecamatan Selupu Rejang Kabupaten Rejang Lebong Bengkulu
}

\author{
Analysis of Profit and Efficiency of Pasteurized Milk Business at Koica Milk Shop in Selupu \\ Rejang, Rejang Lebong, Bengkulu
}

G. D. Waseso, B. Sumantri dan Irnad

Jurusan Sosial Ekonomi Pertanian, Fakultas Pertanian, Universitas Bengkulu

Jl. W.R. Supratman, Kandang Limun, Kota Bengkulu

Koresponden e-mail: gdwaseso@yahoo.com

\begin{abstract}
This study was aimed to calculate the advantages and the efficiency of pasteurization milk processing business in Koica Milk Shop (KMS) located at the center of dairy farms Kec. Selupu Rejang, Kab. Rejang Lebong, Bengkulu Province. Data analysis was done by counting the result of fresh milk production processed for 30 weeks, including: total production cost, business acceptance, profit, and $\mathrm{R} / \mathrm{C}$ ratio. The average total production cost per period is Rp. 3,457,686.67, with average raw material of milk received by manager as much as 263.91 liter per week, KMS able to get profit equal to Rp. 103,093.33 per week with an average value of business efficiency ( $\mathrm{R} / \mathrm{C}$ ) of 1.03 indicated that this business has been efficient and feasible to cultivate.
\end{abstract}

Key words: pasteurized milk, profit, business efficiency

\begin{abstract}
ABSTRAK
Penelitian ini bertujuan untuk menghitung keuntungan dan mengetahui efisiensi usaha pengolahan susu pasteurisasi di Koica Milk Shop (KMS) yang berada di sentra peternakan sapi perah Kec. Selupu Rejang, Kab. Rejang Lebong, Propinsi Bengkulu. Analisis data dilakukan dengan menghitung hasil produksi susu segar yang diolah selama 30 minggu, meliputi : total biaya produksi, penerimaan usaha, keuntungan, dan $\mathrm{R} / \mathrm{C}$ rasio. Total biaya produksi rata-rata setiap periode adalah sebesar Rp. 3,457,686.67, dengan rata-rata bahan baku susu yang diterima pengelola sebanyak 263.91 liter per minggu, KMS mampu mendapatkan keuntungan sebesar Rp. 103.093,33 per minggu dengan nilai rata-rata efisiensi usaha (R/C) sebesar 1,03 menunjukan bahwa usaha ini sudah efisien dan layak untuk diusahakan.
\end{abstract}

Kata kunci : susu pasteurisasi, keuntungan, efisiensi usaha

\section{PENDAHULUAN}

Usaha peternakan sapi perah di Provinsi Bengkulu terdapat di Kab. Rejang Lebong dan Kab. Kepahiang yang memiliki kondisi iklim sesuai dengan fisiologis sapi perah. Populasi sapi perah Di Bengkulu meningkat sejak tahun 2002 ketika Pemerintah Daerah mendatangkan bantuan ternak perah yang berasal dari kawasan Jawa Barat. Selama rentang waktu 2002-2015, usaha ini mengalami pasang surut dan saat ini hanya beberapa peternak saja yang bertahan.

Keberadaan industri pengelola susu (IPS) merupakan salah satu perangkat yang sangat vital bagi kelangsungan usaha peternakan sapi perah, hal ini disebabkan oleh produk susu yang dihasilkan merupakan bahan segar yang sangat rentan terhadap kerusakan sehingga harus cepat dilakukan pengolahan. Salah satu IPS di Kabupaten Rejang Lebong adalah Koica Milk Shop (KMS) yang berdekatan dengan lokasi peternakan di Kelurahan Air Duku Kecamatan Selupu Rejang. Saat ini IPS tersebut memiliki peran sebagai penampung, pengelola dan memasarkan susu hasil produksi. KMS ini membuat produk susu pasteurisasi yang memfaatkan susu segar yang dihasilkan oleh peternak sapi perah di daerah sekitar Rejang Lebong 
sebagai bahan bakunya. Susu segar ini kemudian diolah menjadi beberapa jenis rasa minuman susu pasteurisasi, misalnya susu rasa strawberi, coklat dan kopi. Berbagai jenis produk susu yang dihasilkan ini akan manghasilkan omzet penjualan (penerimaan) yang akan digunakan untuk pengembangan usaha KMS berikutnya.

Agar usaha KMS dapat terus berlangsung, maka harus dipastikan bahwa usaha ini mendapatkan keuntungan. Keuntungan ini akan digunakannya kembali untuk menambah modal usaha untuk membiayai proses produksi yang berlangsung terus menerus. Keuntungan yang maksimal akan menjadi tujuan KMS agar usaha ini dapat berkembang. Oleh karena itu harus dapat dipastikan bahwa usaha KMS ini dikelola secara efisien, dalam arti besarnya penerimaan yang diterima oleh KMS harus dapat tetap membiayai seluruh pengeluarannya pada setiap periode produksi atau satu satuan waktu tertentu.

Kondisi efisien ini harus tetap dipertahankan selama KMS ini berdiri, sehingga diperlukan perhitungan yang terus menerus secara berkala dengan berbagai kondisi perubahan ketersediaan bahan baku dan faktor harganya serta naik turunnya permintaan produk Susu Pasteurisasi di tingkat konsumen yang akan mempengaruhi nilai omset penjualan (penerimaan). Permasalahan pada penelitian ini adalah berapakah keuntungan dan apakah usaha pengolahan susu pasteurisasi pada Koica Milk Shop sudah efisien. Oleh karena itu penelitian ini dilakukan dengan tujuan menghitung keuntungan dan mengetahui efisiensi usaha susu pasteurisasi pada pengelolaan Koica Milk Shop di Kecamatan Selupu Rejang, Kab. Rejang Lebong, Bengkulu.

\section{MATERI DAN METODE}

Penelitian ini dilaksanakan pada Industri Pengolahan Susu (IPS) skala rumah tangga yaitu "Koica Milk Shop" di Kelurahan Air Duku Kecamatan Selupu Rejang Kabupaten Rejang Lebong. Lokasi ditentukan secara sengaja atau Purposive dengan pertimbangan bahwa di lokasi tersebut merupakan satu satunya tempat penampungan susu dari peternak, mengelola serta menjual produknya. Pertimbangan lain yaitu wilayah penelitian merupakan sentra pengembangan peternakan sapi perah. Penelitian dilaksanakan pada bulan April-Mei 2017.

Penelitian ini menggunakan data primer berupa data yang berasal dari usaha pasteurisasi rumah tangga yaitu "Koica Milk Shop" di Kelurahan Air Duku Kecamatan Selupu Rejang Kabupaten Rejang Lebong. Selain itu data sekunder jugadiperlukan dan diperoleh dari literature review. Data primer diperoleh secara langsung dari pengelola usaha berdasarakan rekapitulasi catatan harian bahan baku susu serta dilakukan juga observasi secara langsung, wawancara dan pencatatan proses pengolahan susu pasteurisasi di Koica Milk Shop, sehingga didapatkan gambaran yang jelas mengenai obyek yang diteliti.

Nilai total biaya pada industri pengolahan susu Koica Milk Shop adalah penjumlahan dari nilai total biaya tetap dan nilai biaya variabel yang digunakan dalam kegiatan produksi susu pasteurisasi. Secara matematis dirumuskan sebagai berikut :

$$
\mathrm{TC}=\mathrm{TFC}+\mathrm{TVC}
$$

Keterangan : 
TC $($ Total Cost $)=$ Biaya total pengolahan susu pasteurisasi di Koica Milk Shop (Rupiah).

TFC $($ Total Fixed Cost $)=$ Total biaya tetap pengolahan susu pasteurisasi meliputi biaya penyusutan peralatan dan biaya bunga modal investasi (Rupiah).

TVC $($ Total Variable Cost $)=$ Total biaya variabel pengolahan susu pasteurisasi meliputi biaya bahan baku, biaya bahan penolong, biaya bahan bakar, biaya tenaga kerja, biaya pengemasan, biaya transportasi (Rupiah).

$\mathrm{TFC}=\sum(\mathrm{HBi} / \mathrm{Uei})+$ sewa tempat + Biayabiaya yang pembayarannya tetap selama satu proses produksi

Dimana :

TFC $=$ Total Fixed Cost $/$ Total Biaya Tetap (Rp/Bulan)

$\mathrm{HB}=$ Harga beli peralatan yang digunakan untuk usaha .

$\mathrm{Ue}=$ Umur ekonomis dari setiap peralatan yang digunakan untuk usaha.

$\mathrm{I}=$ Jumlah jenis peralatan yang digunakan untuk usaha

Total biaya variabel merupakan penjumlahan dari seluruh biaya yang disebabkan penggunaan faktor produksi variable setelah dikalikan dengan harga faktor produksi tersebut. Secara matematis dapat diformulasikan sebagai berikut :

$$
\text { TVC }=\sum_{n=1}^{\infty}(\mathrm{Xi} \text { Pxi })
$$

Dimana :

TVC = Total Variable Cost / Total Biaya Variabel (Rp/Bulan)
$\mathrm{Xi}=$ Faktor produksi variabel yang digunakan untuk usaha.

Pxi = Harga faktor produksi variabel yang digunakan untuk usaha .

Penerimaan dari pengolahan susu pasteurisasi di KMS dapat diketahui dengan mengalikan jumlah produk yang terjual dengan harga jual susu tersebut. Metode perhitungan:

$$
\mathbf{T R}=\sum_{n=\mathbf{1}}^{\infty}(\mathbf{Q} \mathbf{P} \mathbf{i})
$$

Dimana:

$\mathrm{TR}($ Total Revenue $)=$ Penerimaan dari KMS (Rupiah)

$\mathrm{Q}($ Quantity $)=$ Jumlah produk yang terjual (cup)

$\mathrm{P}($ Price $)=$ Harga jual susu per cup (Rupiah)

$\mathrm{i}=\operatorname{produk} 1.2 .3 \ldots \ldots . . \mathrm{n}$

Keuntungan didefinisikan sebagai total penerimaan dikurangi total biaya. Dalam definisi keuntungan semua pendapatan dan biaya baik berwujud maupun tidak berwujud harus diperhitungkan. Keuntungan produsen adalah total revenues (TR) dikurangi total cost (TC). Secara matematis dapat dirumuskan sebagai berikut :

$\pi=\mathrm{TR}-\mathrm{TC}$

$\pi=(\mathrm{P} \times \mathrm{Q})-(\mathrm{TFC}+\mathrm{TVC})$

Keterangan:

$\pi=$ Keuntungan

TR $($ total revenues $)=$ Penerimaan total

$\mathrm{TC}($ total cost $)=$ Biaya total industri

$\mathrm{P}($ Price $)=$ Harga jual produk

$\mathrm{Q}($ Quantity $)=$ Jumlah Produk yang diproduksi

TFC $($ Total Fixed Cost $)=$ Total biaya tetap 
TVC $($ Total Variable Cost $)=$ Total biaya variabel

\section{R/C Rasio}

Salah satu cara yang dapat digunakan untuk mengetahui efisiensi industri rumah tangga dapat dengan menghitung $\mathrm{R} / \mathrm{C}$ ratio (Return Cost ratio). R/C Rasio adalah perbandingan antara total penerimaan dengan total biaya. Secara matematis dapat ditulis :

$$
\mathrm{R} / \mathrm{C} \text { Ratio }=\mathrm{TR} / \mathrm{TC}
$$

Keterangan :

$\mathrm{TR}=$ Total Revenue, $\mathrm{TC}=$ Total Cost Kriteria jika

R/C Ratio > 1 : efisien

$\mathrm{R} / \mathrm{C}$ Ratio $=1:$ Impas

R/C Ratio $<1$ : tidak efisien

\section{HASIL DAN PEMBAHASAN}

\section{Produksi Susu Pasteurisasi Di KMS}

Susu pasteurisasi yang dibuat oleh KMS merupakan produk skala usaha mikro.
KMS memanfaatkan susu hasil peternakan sapi perah yang dipelihara oleh peternak yang berada di daerah Rejang Lebong. KMS secara kontinyu memperoleh susu sebagai bahan baku pembuatan susu pasteurisasi. Kontinyuitas ketersediaan bahan baku merupakan salah satu syarat terjaminya keberlangsungan kegiatan agroindustri pada satu daerah.

\section{Penggunaan Bahan Baku}

Bahan baku yang digunakan dalam proses produksi susu pasteurisasi adalah susu segar yang berasal dari para peternak yang berada di Desa Kali Padang dan Kelurahan Air Duku. Jumlah susu yang diterima KMS bergantung pada banyaknya jumlah indukan sapi perah yang sedang laktasi atau menghasilkan susu. Adapun beberapa peternak yang memiliki sumber bahan baku susu untuk produksi susu pasteurisasi di KMS dapat dilihat pada Tabel 1 berikut.

Tabel 3. Peternak, jumlah induk sapi laktasi dan jumlah susu yang dihasilkan sebagai sumber bahan baku di KMS pada saat penelitian

\begin{tabular}{lccl}
\hline Nama peternak & $\begin{array}{c}\text { Jumlah induk sapi } \\
\text { laktasi (ekor) }\end{array}$ & $\begin{array}{c}\text { Jumlah susu } \\
\text { (liter/hari) }\end{array}$ & Alamat \\
\hline Suwandono & 2 & 10 & Kelurahan Air Duku \\
Kusnendi & 1 & 6 & Desa Kali Padang \\
Nasip & 2 & 6 & Desa Kali Padang \\
Sofiyan Efendi & 3 & 20 & Desa Kali Padang \\
\hline
\end{tabular}

\section{Proses Produksi Pembuatan Susu Pasterurisasi di KMS}

Sebelum dilakukan tahapan proses pembuatan susu pasteurisasi, penerimaan susu dari peternak melalui perlakuan uji kualitas air susu dengan uji alkohol. Proses produksi susu pasteurisasi di KMS dilakukan secara sederhana menggunakan metode batch system dengan teknologi yang didesain khusus untuk industri kecil atau home industry pengolahan susu pasteurisasi. 


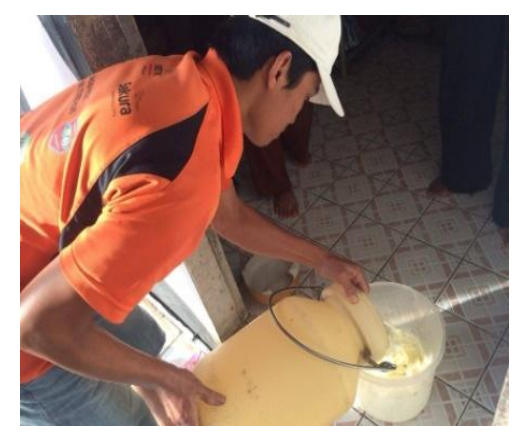

(a)

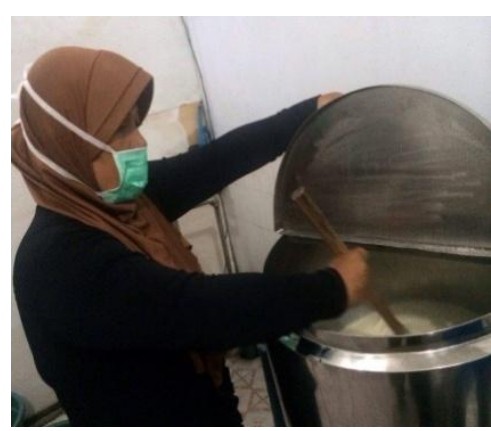

(b)

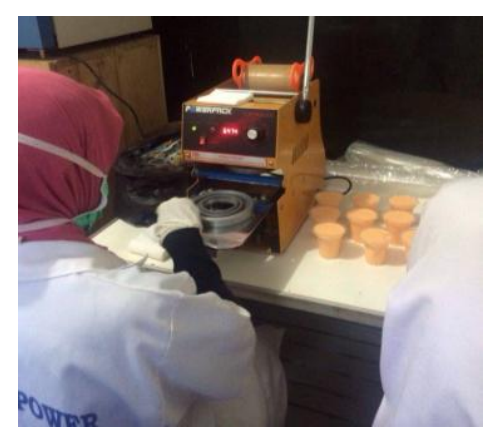

(c)

Gambar 1.(a) Penerimaan susu dari peternak, (b) Proses pasteurisasi, (c) Proses pengemasan produksi.

Pengujian dengan menggunakan alkohol dilakukan dengan menggunakan alat gun test yang telah diisi dengan alkohol $70 \%$ untuk mengetahui apakah protein pada susu tersebut telah terdenaturasi/ pecah atau tidak. Prinsip uji alcohol pada susu adalah menambah alkohol $70 \%$ ke dalam susu dengan perbandingan 1:1. Susu yang hasilnya bagus menunjukkan alkohol negatif berarti protein pada susu belum pecah. Begitu juga sebaliknya, susu dikatakan positif apabila proteinnya sudah pecah dan susu mengalami penggumpalan (Meisya, 2011)

Batch System merupakan metode pemanasan susu pada suhu $61-63^{\circ} \mathrm{C}$ selama 30 menit dan secepatnya diikuti dengan pendinginan untuk mencegah tumbuhnya bakteri yang masih dapat hidup pada suhu pasteurisasi. Caranya susu dipanaskan dengan menempatkannya pada wadah yang berisi air, lalu dilakukan pendinginan. Suhu yang lebih tinggi biasanya digunakan pada skala kecil dimana waktu yang digunakan lebih pendek, misalnya $155^{\circ} \mathrm{F}$ atau $68.3^{\circ} \mathrm{C}$ selama 20 menit atau $165^{\circ} \mathrm{F}$ $\left(73.9^{\circ} \mathrm{C}\right)$ selama 15 menit, kontrol terhadap suhu dan lama pemanasan sangat penting.

Penggunaan suhu diatas $63^{\circ} \mathrm{C}$ dapat menyebabkan perubahan fisik dari keadaan susu yang mengakibatkan menipisnya lapisan krim pada permukaan sehingga konsumen dapat menganggap bahwa susu tersebut lemaknya rendah. Dalam skala rumah tangga, secara sederhana pasteurisasi batch dapat dilakukan dengan steam. Hindari pemanasan susu secara langsung di atas api hingga mendidih. Tujuannya untuk mencegah kerusakan pada komponen-komponen susu, terutama kerusakan laktosa dan timbulnya flavour gosong (Roseli, 2017).

\section{Perkembangan Produksi dan Harga Susu Pasteurisasi di KMS}

Produksi susu pasteurisasi di KMS mengalami fluktuasi kuantitas tergantung pada jumlah susu yang dihasilkan oleh peternak. KMS dalam memproduksi susu pasteurisasi menyesuaikan dengan permintaan pasar. Penerimaan susu oleh KMS menyesuaikan dengan permintaan pasar. Jika permintaan pasar tinggi maka banyaknya susu yang dihasilkan peternak akan ditampung semua oleh KMS, sedangkan jika permintaan pasar turun maka pihak KMS akan mengurangi kuantitas produksi susu pasteurisasinya meskipun produksi susu dari peternak sedang tinggi. Meskipun demikian, perkembangan harga susu segar di Kecamatan Selupu Rejang mengalami peningkatan setiap tahun. Tabel 2 berikut menyajikan perkembangan harga susu segar yang diterima peternak dari pihak KMS. 
Tabel 4. Perkembahan harga dan produksi berbagai macam bentuk susu pasteurisasi yang dihasilkan oleh KMS

\begin{tabular}{ccc}
\hline Tahun & Harga bahan baku $(\mathrm{Rp} /$ liter $)$ & Haga susu pasteurisasi $(\mathrm{Rp} /$ liter $)$ \\
\hline 2013 & $4.500,00$ & $8.000,00$ \\
2014 & $5.000,00$ & $9.000,00$ \\
2015 & $5.500,00$ & $10.000,00$ \\
2016 & $6.000,00$ & $14.000,00$ \\
2017 & $7.000,00$ & $15.000,00$ \\
\hline
\end{tabular}

Tabel diatas menunjukkan tingkat perkembangan harga susu segar yang diterima peternak setiap tahun. Pada tahun 2013 harga susu segar yang dibayarkan oleh pihak KMS yaitu sebesar Rp. 4.500,00 per liter dan harga jual setelah menjadi produk susu pasteurisasi menjadi Rp. 8.000,00. Peningkatan harga susu yang signifikan setiap tahun dipengaruhi oleh kekurangan produksi susu pada saat permintaan konsumen sedang naik. Pada pertengahan tahun 2017 harga susu segar naik dari Rp. 6.000,00 per liter menjadi Rp. 7.000,00 per liter dengan harga jual produk susu pasteurisasi Rp. 15.000,00 per liter.

\section{Penggunaan Faktor Produksi Usaha Pembuatan Susu Pasteurisasi di KMS}

Produksi fisik usaha susu pasteurisasi dihasilkan oleh bekerjanya beberapa faktor produksi sekaligus, yaitu bahan baku susu segar, modal usaha, dan tenaga kerja. Arta (2014) menyatakan gambaran atau analisis peranan masingmasing faktor produksi terhadap produksi fisik dari sejumlah faktor produksi yang digunakan, salah satu faktor produksi dianggap sebagai variabel (berubah-ubah), sementara faktor produksi lainnya diasumsikan konstan (tidak berubah). Hubungan fungsional tersebut berlaku untuk semua faktor produksi.

\section{Penggunaan Faktor Produksi Tetap}

Penggunaan faktor produksi tetap pada usaha susu pasteurisasi di KMS meliputi gedung operasional, mesin pasteurisasi, lemari pendingin atau show chase, freezer, cup sealer, biaya listrik dan biaya air.

Tabel 5. Faktor produksi tetap yang digunakan dalam usaha pengolahan susu pasteurisasi di KMS

\begin{tabular}{llllr}
\hline No & $\begin{array}{l}\text { Jenis Faktor Produksi } \\
\text { Tetap }\end{array}$ & $\begin{array}{l}\text { Jumlah yang } \\
\text { digunakan (unit) }\end{array}$ & $\begin{array}{l}\text { Tahun } \\
\text { Pembelian }\end{array}$ & $\begin{array}{l}\text { Harga beli } \\
\text { (Rp/unit) }\end{array}$ \\
\hline 1 & Gedung & 1 & 2005 & $39.900 .000,00$ \\
2 & Mesin pasteurisasi & 1 & 2005 & $25.000 .000,00$ \\
3 & Show Chase & 2 & 2016 & $6.000 .000,00$ \\
4 & Freezer & 1 & 2016 & $5.000 .000,00$ \\
5 & Cup Seeler & 2 & 2015 & $2.500 .000,00$ \\
6 & Kompor & 1 & 2005 & $420.000,00$ \\
7 & Listrik & & & $400.000,00$ \\
8 & Air & & $10.000,00$ \\
\hline
\end{tabular}

Sumber : Data primer 2017

Faktor produksi tetap yang mendukung berlangsungnya kegiatan usaha susu pasteurisasi di KMS antara lain satu unit bangunan gedung dengan luas 80 $\mathrm{m}^{2}$ terdiri dari ruang pengolahan dan ruang pemasaran. Adapun peralatan yang digunakan antara lain mesin pasteurisasi satu unit, Show chase 2 unit, freezer 1 unit, cup seeler 2 unit, kompor 1 unit. Faktor tetap yang lain yaitu berupa biaya listrik 
dan air yang dibayarkan setiap bulan dengan besaran yang berubah-ubah.

\section{Penggunaan Faktor Produksi Variabel}

Faktor produksi variabel merupakan penentu utama berlangsungnya usaha produksi susu pasteurisasi karena bahan baku utama berupa susu segar. Bahan bahan pelengkap yang digunakan pada usaha ini antara lain gula pasir, pasta atau perisa makanan, cup plastik, straw atau pipet, seal cup dan tenaga kerja. Rincian penggunaan faktor produksi variabel terdapat pada tabel 4 .

Tabel 6. Faktor produksi variabel yang digunakan dalam usaha pengolahan susu pasteurisasi di KMS

\begin{tabular}{llllr}
\hline No & $\begin{array}{c}\text { Jenis faktor } \\
\text { produksi variabel }\end{array}$ & $\begin{array}{c}\text { Rata-rata penggunaan } \\
\text { per mingu }\end{array}$ & \multicolumn{1}{c}{ Satuan } & \multicolumn{1}{c}{$\begin{array}{c}\text { Harga pembelian } \\
\text { (Rp/satuan) }\end{array}$} \\
\hline 1 & Susu segar & 263,91 & liter & $7.000,00$ \\
2 & Gula pasir & 52,78 & $\mathrm{~kg}$ & $13.000,00$ \\
3 & Pasta & 527,83 & $30 \mathrm{ml} / \mathrm{botol}$ & $1.500,00$ \\
4 & Cup plastic & 1.055 & Unit & 70,00 \\
5 & Straw & 0,25 & $\mathrm{Kg}$ & $60.000,00$ \\
6 & Seal cup & 1.055 & Unit & 70,00 \\
7 & Tenaga kerja & 28 & HOK & $40.000,00$ \\
\hline
\end{tabular}

Sumber : Data primer yang telah diolah, 2017

Susu segar merupakan faktor produksi utama atau kebutuhan dasar yang menentukan kelangsungan usaha susu pasteurisasi. Produksi susu dan permintaan pasar menjadi penentu harga pembelian susu segar dari peternak dan penjualan hasil produksi susu pasteurisasi oleh KMS. Perhitungan selama 30 minggu produksi pada tabel 5 diatas menunjukan bahwa jumlah rata-rata susu yang dikelola oleh KMS mencapai 263,92 liter per minggu.

Gula pasir sebagai sumber bahan pemanis pada susu pasteurisasi merupakan bahan penunjang. Kebutuhan gula pasir yang digunakan sebanyak $6 \%$ dari jumlah susu segar yang akan diproduksi menjadi produk susu pasteurisasi. Gula yangdigunakan yaitu jenis gula industri yang telah sesuai dengan standarisasi yang dibeli pada produsen tetap. Pasta atau perisa makanan merupakan bahan tambahan makanan yang memberikan aroma tertentu pada produk pangan olahan yang dihasilkan. Bahan yang dikenal juga dengan istilah flavour ini merupakan kombinasi antara warna dan aroma.
Plastic Cup dan seal cup merupakan bahan pengemas yang dipakai untuk produksi susu pasteurisasi di KMS, merupakan cup aseptis dengan bahan food grade menggunakan penutup metalizing. Bahan pengemas tersebut memiliki kualifikasi aman apabila dipergunakan secara aseptis. Fungsi utama pengemasan yaitu untuk melindungi produk dari kerusakan unsur luar. Kerusakan bahan atau produk yang berasal dari dalam tidak dapat dilakukan hanya dengan pengemasan. SK Menkes No.23/Men.Kes/1978 menyatakan bahwa wadah pengemas untuk pangan harus dapat melindungi dan mempertahankan mutu serta isinya dari pengaruh luar, dibuat dari bahan yang tidak melepaskan unsur-unsur yang dapat mengganggu kesehatan atau mempengaruhi mutu makanan, menjamin keutuhan dan keaslian isinya serta tahan terhadap perlakuan panas selama pengolahan dan pengangkutan, sedangkan Straw merupakan bahan pelengkap kemasan yang digunakan sebagai alat minum susu berbentuk sedotan. 
Tenaga kerja merupakan penduduk yang sudah atau sedang bekerja, yang sedang mencari pekerjaan dan melakukan kegiatan lain seperti bersekolah dan mengurus rumah tangga. Sebagian besar tenaga kerja di Indonesia masih menggantungkan hidupnya dari sektor pertanian. Dalam usahatani sebagian besar tenaga kerja berasal dari keluarga petani sendiri yang terdiri dari ayah sebagai kepala keluarga, istri, dan anak-anak petani. Tenaga kerja yang berasal dari keluarga petani ini merupakan sumbangan keluarga pada produksi pertanian secara keseluruhan dan tidak pernah dinilai dengan uang (Mubyarto, 1989). Ukuran tenaga kerja dapat dinyatakan dalam hari orang kerja (HOK).

\section{Total Biaya Usaha Pengolahan Susu Pasteurisasi di KMS}

Keseluruhan biaya yang dikeluarkan pihak KMS dalam memproduksi susu pasteurisasi terdiri dari biaya yang bersal dari faktor produksi tetap dan faktor produksi tidak tetap atau faktor variabel. Besarnya biaya total yang dikeluarkan oleh pihak KMS setiap periode produksi tidaklah sama, tergantung pada jumlah bahan baku susu segar yang diterima. Semakin banyak jumlah susu yang diterima, maka akan meningkatkan biaya produksi yang berasal dari faktor produksi variabel yang meliputi bahan kemasan dan bahan pelengkap.

\section{Biaya Tetap Usaha Pengolahan Susu Pasteurisasi di KMS}

Biaya tetap pada usaha pengolahan susu pasteurisasi merupakan beberapa biaya yang harus dikeluarkan KMS untuk modal kerja yang tidak tergantung dengan besar kecilnya jumlah produksi yang akan dihasilkan. Pada usaha pengelolaan susu pasteurisasi di KMS terdapat beberapa pengeluaran yang menjadi biaya tetap meliputi : penyusutan gedung, penyusutan mesin pasteurisasi, peyusutan show chase, penyusutan freezer, penyusutan cup seler, biaya listrik, biaya air dan peralatan lainlain. Rincian biaya tetap yang harus dikeluarkan oleh usaha susu pasteurisasi di KMS terdapat pada Tabel 5.

Biaya tetap dijelaskan pada Tabel 5 antara lain dari 1 unit gedung yang digunakan untuk beroperasinya pengolahan susu pasteurisasi di KMS dengan modal awal pembangunan pada tahun 2005 sebesar Rp. 39.900.000,00 dengan umur ekonomis atau masa penggunaan selama 25 tahun memiliki total nilai penyusustan sebesar Rp. 1.596.000,00 per tahun. Mesin pasteurisasi yang digunakan dengan harga Rp. 25.000.000,00 memiliki umur ekonomis selama 25 tahun, sehingga dapat diketahui nilai penyusutannya sebesar Rp. 1.000.000,00 per tahun. Lemari penyimpanan susu atau show chase senilai Rp. 6.000.000,00 dengan umur ekonomis 10 tahun. Lemari pendingin atau freezer dengan harga awal Rp. 5.000.000,00 memiliki umur ekonomis selama 12 tahun. Mesin cup seeler yang digunakan untuk menutup kemasan produk susu pasteurisasi dengan harga awal Rp. 2.500.000,00 memiliki umur ekonomis 5 tahun. Sementara itu untuk kompor gas biaya penyusutannya mencapai Rp. 420.000,00 per tahun. Kebutuhan tenaga listrik untuk mengoperasikan mesin mesin di KMS biaya tetap yang harus dikeluarkan pihak pengelola mencapai Rp. 4.800.000,00 per tahun, sedangkan kebutuhan air untuk sanitasi dan kebersihan peralatan produksi berasal dari Perusahaan Air Swadaya yang berada di lokasi KMS dengan biaya total satu tahun sebesar Rp. 120.000,00 per tahun. 
Tabel 5. Biaya tetap per minggu pada usaha pengolahan susu pasteurisasi di KMS

\begin{tabular}{lcrcrr}
\hline $\begin{array}{c}\text { Jenis faktor } \\
\text { produksi }\end{array}$ & Jumlah & $\begin{array}{c}\text { Harga beli } \\
(\mathrm{Rp})\end{array}$ & $\begin{array}{c}\text { Umur } \\
\text { ekonomis } \\
\text { (Tahun) }\end{array}$ & $\begin{array}{c}\text { Biaya/bulan } \\
(\mathrm{Rp})\end{array}$ & $\begin{array}{c}\text { Biaya/minggu } \\
(\mathrm{Rp})\end{array}$ \\
\hline Gedung & 1 & $39.900 .000,00$ & 25 & $133.000,00$ & $31.033,31$ \\
Mesin & 1 & $25.000 .000,00$ & 25 & $83.333,33$ & $19.444,46$ \\
Show Chase & 1 & $6.000 .000,00$ & 10 & $50.000,00$ & $11.666,69$ \\
Freezer & 1 & $5.000 .000,00$ & 12 & $34.722,25$ & $8.101,87$ \\
Cup Seeler & 1 & $2.500 .000,00$ & 5 & $83.333,33$ & $19.444,46$ \\
Kompor gas & 4 & $420.000,00$ & 1 & $35.000,00$ & $8.166,69$ \\
Listrik & & & & $400.000,00$ & $93.333,31$ \\
Air & & & & $829.000,00$ & $2.333,31$ \\
\hline Total & & & & & \\
\hline
\end{tabular}

Sumber : Data primer yang telah diolah, 2017

Tabel 5 menunjukkan rata-rata biaya tetap/penyusutan setiap bulan pada proses produksi susu pasteurisasi KMS adalah Rp. 829.388,92. Berdasar hasil perhitungan biaya tetap/penyusutan per bulan tersebut, maka dapat dihitung rata-rata biaya tetap/penyusutan per minggu selama masa penelitian adalah sebesar Rp 193.524,00.

\section{Biaya Variabel}

Biaya variabel adalah biaya yang digunakan dalam proses pembuatan susu pasteurisasi yang besarnya berubah-ubah secara proporsional terhadap kuantitas output yang dihasilkan. Biaya-biaya yang termasuk dalam biaya variabel pengolahan susu pasteurisasi yang dikeluarkan oleh KMS di Kecamatan Selupu Rejang adalah biaya bahan baku, bahan penolong, biaya pengemasan dan biaya tenaga kerja yang dinyatakan dalam satuan rupiah. Perhitungan biaya bahan baku pada pengolahan susu pasteurisasi di KMS satu periode produksi dilakukan satu minggu sekali sesuai dengan pembayaran total pembelian susu segar kepada peternak. Hasil perhitungan rata-rata jumlah susu segar yang diterima pengelola susu pasteurisasi di KMS setiap minggu mencapai 263,91 liter dengan harga beli
Rp. 7.000,00 per liter; sehingga diketahui rata-rata jumlah modal yang dibutuhkan KMS untuk membeli bahan utama susu segar dari peternak sebesar Rp. 1.847.393,33. Jumlah susu tersebut menjadi panduan dalam menghitung kebutuhan gula, sealer, cup dan pasta atau penambah aroma.

Asumsi yang digunakan untuk menghitung kebutuhan gula yang dibutuhkan pada tabel 4 untuk setiap liter susu adalah $20 \%$, sedangkan setiap liter susu dikemas dengan ukuran $250 \mathrm{ml}$, sehingga kebutuhan cup dan sealer merupakan perkalian antara total susu dengan 4 cup. Kebutuhan pasta diasumsikan sebanyak $0,2 \%$ per liter susu, setiap $30 \mathrm{ml}$ per botol dengan harga $\mathrm{Rp}$. 1.500,00. Pembelian sealer untuk setiap seribu unit dihargai sebesar Rp. 70.000,00, cup $200 \mathrm{ml}$ seharga Rp. 70.000,00 untuk setiap seribu unit, biaya pasta per botol (30 ml) Rp. 1.500,00 biaya gula per kilogram Rp 13.000,00 biaya susu segar yang dibayarkan ke peternak Rp. 7.000,00 per liter. Perhitungan besarnya biaya bahan pengolahan susu pasteurisasi rata-rata per minggu selama 30 minggu penelitian disajikan pada Tabel 6. 
Tabel 6. Rata-rata biaya bahan per minggu pada pengolahan susu pasteuriasi di KMS

\begin{tabular}{lrrr}
\hline \multicolumn{1}{c}{ Variabel pengeluaran } & \multicolumn{1}{c}{ Jumlah } & Harga (Rp/unit) & \multicolumn{1}{c}{ Biaya (Rp) } \\
\hline Susu (Liter) & 263,91 & $7.000,00$ & $1.847 .393,33$ \\
Gula (Kg) & 52,78 & $13.000,00$ & $686.174,67$ \\
Sealer (unit) & $1.055,65$ & 70,00 & $73.895,73$ \\
Cup (unit) & $1.055,65$ & 70,00 & $73.895,73$ \\
Pasta (ml) & 527,83 & 50,00 & $26.391,33$ \\
\hline Total & & & $2.707 .750,79$ \\
\hline
\end{tabular}

Sumber: Data primer yang telah diolah, 2017

Biaya tenaga kerja meliputi seluruh biaya yang dikeluarkan untuk membayar gaji dan upah pengelola usaha dan karyawan yang langsung terkait dengan proses produksi. Penggunaan tenaga kerja dalam setiap tahapan seluruhnya digunakan tenaga kerja keluarga, waktu yang dibutuhkan untuk pengolahan susu pasteurisasi tidak memerlukan waktu yang lama ataupun tenaga yang banyak, hal ini dikarenakan skala usahanya masih tergolong kecil berkaitan dengan total bahan baku susu yang diterima pihak KMS tidak banyak. Biaya tenaga kerja dibayarkan setiap hari apabila ada aktivitas produksi sebesar $\mathrm{Rp}$ 50.000,00 untuk Ketua pengelola, Rp 45.000,00 untuk bendahara dan $\mathrm{Rp} \quad 40.000,00$ untuk masing-masing karyawan.
Berdasar hasil perhitungan rata-rata biaya tenaga kerja per minggu yang dibayarkan selama 30 minggu selama penelitian adalah sebesar Rp 1.219.166,67.

\section{Produksi dan Penerimaan Usaha Pengolahan Susu Pasteurisasi}

Penerimaan usaha pengolahan susu pasteurisasi di KMS dihitung berdasarkan hasil produksi setiap periode selama satu minggu berasal dari penjualan susu pasteurisasi dengan berbagai varian rasa. Penerimaan usaha pengolahan susu pasteurisasi diperoleh dengan cara mengalikan jumlah produk yang dihasilkan dalam kemasan cup $250 \mathrm{ml}$ dengan harga jual Rp.4.000,00. Penerimaan rata-rata yang diperoleh selama 30 minggu oleh KMS mencapai Rp. 4.222.613,33 dengan rincian pada Tabel 7 berikut ini.

Tabel 7. Rata-rata penerimaan per minggu pada usaha pengolahan susu pasteurisasi di KMS

\begin{tabular}{llrrrr}
\hline No & $\begin{array}{c}\text { Jenis Produk susu } \\
\text { pasteurisasi yang } \\
\text { dihasilkan }\end{array}$ & $\begin{array}{c}\text { Jumlah yang } \\
\text { diproduksi (unit/ } \\
\text { minggu) }\end{array}$ & $\begin{array}{c}\text { Harga jual setiap } \\
\text { jenis Produk (Rp) }\end{array}$ & $\begin{array}{c}\text { Tempat } \\
\text { penjualan }\end{array}$ & $\begin{array}{r}\text { Penerimaan } \\
\text { (Rp/minggu) }\end{array}$ \\
\hline 1 & Rasa Strawberi & 291,67 & $4.000,00$ & Kios KMS & $1.166 .666,67$ \\
2 & Rasa Mocca & 271,47 & $4.000,00$ & Kios KMS & $1.085 .866,67$ \\
3 & Rasa Vanila & 249,13 & $4.000,00$ & Kios KMS & $996.533,33$ \\
4 & Rasa Jeruk & 243,39 & $4.000,00$ & Kios KMS & $973.546,67$ \\
\hline & Total & $1.055,65$ & & & $4.222 .613,33$ \\
\hline
\end{tabular}

Sumber: Data primer yang telah diolah, 2017

\section{Keuntungan}

Keuntungan usaha susu pasteurisasi diperoleh dengan cara mengurangi penerimaan dengan total biaya produksi. Total biaya produksi usaha pasteurisasi merupakan gabungan dari biaya tetap (penyusutan peralatan) dan biaya tidak tetap (biaya bahan dan biaya tenaga kerja). Rata-rata keuntungan usaha susu 
Tabel 8. Rata-rata keuntungan per minggu dan efisiensi usaha pada pengolahan susu pasteurisasi di KMS

\begin{tabular}{lr}
\hline Uraian & \multicolumn{1}{c}{ Nilai } \\
\hline Rata-rata penerimaan (dari Tabel 7) (Rp) & $4.222 .613,33$ \\
Rata-rata biaya produksi (biaya penyusutan+biaya bahan + biaya tenga & $4.119 .520,00$ \\
kerja) (Rp) & \\
Rata-rata keuntungan (Rp) & $103.093,33$ \\
Efisiensi Usaha (rata-rata penerimaan/rata-rata biaya produksi) & 1,03 \\
\hline
\end{tabular}

Sumber : Data primer yang telah diolah, 2017

Dari Tabel 8 dapat dilihat bahwa rata-rata keuntungan per minggu usaha susu pasteurisasi KMS selama 30 minggu selama penelitian mencapai Rp. 103.093,33. Adanya keuntungan dalam usaha ini, menunjukkan bahwa selama 30 minggu tersebut usaha ini dapat terus berjalan, meskipun besarnya keuntungan per minggunya tidak sama dan bahkan selama 30 minggu tersebut dapat terkumpul dana sekitar Rp 3.092.800,00 yang dapat digunakan untuk memperbesar atau mengembangkan usaha.

\section{Efisiensi Usaha}

Efisiensi merupakan ukuran dalam mencapai produksi yang didapat dari suatu kesatuan biaya, kemudian input-output ratio yang juga dapat dijadikan dasar dalam menentukan nilai efisiensi apabila nilai efisiensi usaha $(\mathrm{R} / \mathrm{C})>1$, dalam hal ini apabila nilai efiensi lebih dari satu maka usaha dikatakan sudah efisien dan juga semakin besar pula keuntungan yang akan diperoleh. Nilai efisiensi usaha pengolahan susu pasteurisasi di KMS diperoleh dengan membagi penerimaan dengan biaya produksi. Dari Tabel 8 diketahui bahwa nilai rata-rata efisiensi usaha yang diperoleh pada usaha pengolahan susu pasteurisasi di KMS dapat dikatakan efisien karena nilainya 1,03. Rahayu dan Riptanti (2010) menyatakan bahwa efisiensi menunjukkan perbandingan antara nilai produk marginal terhadap nilai faktor produksi. Suatu proses produksi dikatakan lebih efisien secara teknik dibanding proses produksi lainnya apabila dapat menghasilkan produksi yang lebih tinggi jumlahnya untuk satu satuan faktor produksi yang digunakan.

\section{KESIMPULAN}

Berdasarkan hasil analisis data terkait usaha susu pasteurisasi di Koica Milk Shop selama 30 minggu disimpulkan bahwa dengan rata-rata bahan baku susu yang diterima sebanyak 263,91 liter per minggu, Koica Milk Shop mampu mendapatkan keuntungan sebesar Rp. 103.093,33 per minggu. Nilai rata-rata efisiensi usaha (R/C) sebesar 1,03 yang menunjukkan bahwa usaha ini efisien dan layak untuk terus diusahakan.

\section{DAFTAR PUSTAKA}

Arta, S. B., D. H. Darwanto dan Irham. 2014. Analisis Efisiensi Alokatif Faktor-Faktor Produksi Sorgum di Kabupaten Gunung Kidul. Agro Ekonomi. 24(1): 77-83.

Meisya, N. 2011. Strategi Pemasaran Susu Pasteurisasi di Koperasi Produksi Susu (KPS) Bogor, Jawa Barat. 
e-ISSN 2528-7109

p-ISSN 1978-3000

Skripsi. Departemen Agribisnis,

Fakultas Ekonomi dan Manajemen

Institut Pertanian Bogor. Diakses pada 24 June 2017.

http://repository.ipb.ac.id/bitstream/h andle/123456789/47622/H11nme.pdf ?sequence $=1 \&$ is Allowed $=\mathrm{y}$.

Mubyarto. 1989. Pengantar Ekonomi Pertanian. LP3ES. Jakarta

Rahayu, W. and E.W. Riptanti. 2010. Analisis Efisiensi Ekonomi Penggunaan Faktor-Faktor Produksi pada Usahatani Kedelai di Kabupaten Sukoharjo. Caraka TaniJurnal Ilmu Ilmu Pertanian, 25(1) :119-125.

Roseli, W. Membuat Susu Pasteurisasi | BBPP Batu. Accessed June 4, 2017. http://bbppbatu.bppsdmp.pertanian.g o.id/membuat-susu-pasteurisasi/.

Tim Komoditi Analis. 2014. Tinjauan Pasar Susu Kental Manis. Kementerian Perdagangan Republik Indonesia. 